\title{
The importance of plant diversity in maintaining the pollinator bee, Eulaema nigrita (Hymenoptera: Apidae) in sweet passion fruit fields
}

\author{
Cláudia Inês da Silva ${ }^{*}$, Natali Gomes Bordon ${ }^{2}$, Léo Correia da Rocha Filho ${ }^{1} \&$ \\ Carlos Alberto Garófalo ${ }^{1}$ \\ 1. Universidade de São Paulo, Faculdade de Filosofia Ciências e Letras, Departamento de Biologia, Av. Bandeirantes \\ 3900, 14040-901, Ribeirão Preto-SP, Brazil; claudiainess@gmail.com, correiadarocha@yahoo.com.br, \\ garofalo@ffclrp.usp.br \\ 2. Instituto Nacional de Pesquisas da Amazônia, Departamento de Botânica, Av. André Araújo 2936, 69060-001, \\ Manaus-AM, Brazil; natalibordon@yahoo.com.br \\ * Correspondence
}

Received 11-X-2011. Corrected 20-V-2012. Accepted 14-VI-2012.

\begin{abstract}
The euglossine bee Eulaema nigrita plays an important role for the pollination of native and economically important plants, such as the sweet passion-fruit Passiflora alata. E. nigrita uniquely collects the nectar from the flowers of $P$. alata, nevertheless, it needs to visit other plants to collect pollen, nectar and other resources for its survival. There are two methods to identify the species of plants used by bees in their diet: by direct observation of the bees in the flowers, and through identification of pollen grains present in brood cells, feces, or in the bees' body. In order to identify the other plants that E. nigrita visits, we analyzed samples of pollen grains removed from the bee's body in the course of the flowering period of P. alata. Among our results, the flora visited by E. nigrita comprised 40 species from 32 genera and 19 families, some of them used as a pollen source or just nectar. In spite of being a polyletic species, E. nigrita exhibited preference for some plant species with poricidal anthers. P. alata which has high sugar concentration nectar was the main source of nectar for this bee in the studied area. Nonetheless, the pollinic analysis indicated that others nectariferous plant species are necessary to keep the populations of E. nigrita. Studies such as this one are important since they indicate supplementary pollen-nectar sources which must be used for the conservation of the populations of E. nigrita in crops neighbouring areas. In the absence of pollinators, growers are forced to pay for hand pollination, which increases production costs; keeping pollinators in cultivated areas is still more feasible to ensure sweet passion fruit production. Rev. Biol. Trop. 60 (4): 1553-1565. Epub 2012 December 01.
\end{abstract}

Key words: bee, conservation, maintenance of pollinators, pollinic analysis.

Animal pollination is one of nature's crucial ecosystem services. The majority of wild plant species and even many crops depend on animals to be pollinated (Crane \& Walker 1984, Daily 1997, Nabham \& Buchmann 1997, Kearns et al. 1998, Kremen et al. 2007, Ricketts et al. 2008, Ollerton et al. 2011). According to Roubik (1995), approximately half of all pollinators of tropical plants are bees, which improve the pollination of at least $72 \%$ of 1 330 crop species. Among bees, those belonging to the tribes Centridini and Euglossini can be considered key pollinators in tropical ecosystems (Schlindwein 2000).

Eulaema nigrita Lepeletier, 1841 is an important euglossine species of the Brazilian bee fauna. The geographic range of this species extends from Costa Rica to Northern Argentina (Roubik \& Hanson 2004), within which the bees are most commonly encountered in open areas, such as the Cerrado vegetation of Brazil (Rebêlo \& Garófalo 1997, Nemésio \& Faria-Jr 2004, Alvarenga et al. 2007). E. nigrita plays an important role for the pollination of native 
and economically important plants such as, Campomanesia pubescens (Myrtaceae) (Torezan-Silingardi \& Del-Claro 1998, Gressler et al. 2006), Chamaecrista debilis (Vogel) Irwin \& Barneby (Fabaceae-Caesalpiniaceae) (Nascimento \& Del-Claro 2007), Adenocalymma bracteatum (Bignoniaceae) (Almeida-Soares et al. 2010), achiote Bixa orellana L. (Bixaceae) (Almeida \& Pinheiro 1992), Brazil nut Bertholletia excelsa H.B.K. (Lecythidaceae) (Maués 2002), guava Psidium guajava L. (Myrtaceae) (Boti 2001), and sweet passion-fruit Passiflora alata Curtis (Passifloraceae) (Varassin \& Silva 1999). Among these plant species, sweet passion-fruit obligatorily depends on crosspollination for successful fruit production.

In recent studies carried out in Uberlândia, state of Minas Gerais, and São Francisco do Itabopoana, state of Rio de Janeiro, Brazil, Gaglianone et al. (2010) reported that Epicharis flava Friese, 1900 (Centridini) was the most frequent pollinator of $P$. alata in both areas and Eulaema species were also considered as potential pollinators. According to those authors, E. nigrita visited the flowers of $P$. alata exclusively for nectar collection. This indicates that pollen, another resource necessary for adult survival and brood production, must be obtained from other plants as it was already observed to Xylocopa species, important pollinators of other Passiflora species, like Passiflora edulis f. flavicarpa Deg. (Silva et al. 2010a).

Conservation of natural areas at the surroundings of crops and the pattern of floral resources used by bees vary according to food plants' availability at a spatiotemporal scale (Kremen et al. 2007, Ricketts et al. 2008, Silva 2009). The knowledge of such patterns is of fundamental importance since it provides support to determine the plants that may be used in the conservation and maintenance of bee populations at the surrounding areas of passion-fruit crops. There are two methods to identify the species of plants used by bees in their diet: by direct observation of the bees in the flowers (Antonini \& Martins 2003, Andena et al. 2005) and through identification of pollen grains present in brood cells, feces, or in the bees' body (males and females) (Silva et al. 2010a). During the collection of floral resources, both male and female touch the anthers leaving the pollen grains adhered to their body. So, the pollen grains deposited on the males' body indicate the nectar sources, while those deposited on the females indicated both, nectar and pollen sources. Therefore, the pollen grains are natural markers of floral resources used by bees as food for adults and immatures, as observed by Silva et al. (2010a, b). For that reason the pollinic analysis is an important tool in the investigation of the plants which maintain the bees. This study aimed to identify the species of native plants that are visited and used by E. nigrita in their diet during the flowering of sweet passion fruit. This information will be very important since they will indicate supplementary pollennectar sources which must be used for the conservation of the populations of E. nigrita in neighbouring areas to the crops.

\section{MATERIAL AND METHODS}

Study area: This study was carried out at Campo Alegre farm, Uberlândia-Minas Gerais State, Brazil (18 59'17' S - 48 14 '35' W) during the flowering period of $P$. alata in the study region (October 2006-May 2007). The farm comprises a total area of 114 ha, of which $20 \%$ is protected as reserve, one hectare is occupied by commercial cultivation of $P$. alata and seven hectares are occupied by Passiflora edulis f. flavicarpa.

The local climate has two well-defined seasons: a cool/dry season extending from MarchSeptember, and a hot/wet season extending from October-February. During the study period, the mean monthly temperature ranged from $20.0-26^{\circ} \mathrm{C}$, and the precipitation ranged from 11-84mm (Fig. 1). Records on temperature and precipitation were obtained from the Laboratório de Climatologia e Recursos Hídricos, da Estação Climatológica da Universidade Federal de Uberlândia, MG (Fig. 1). 


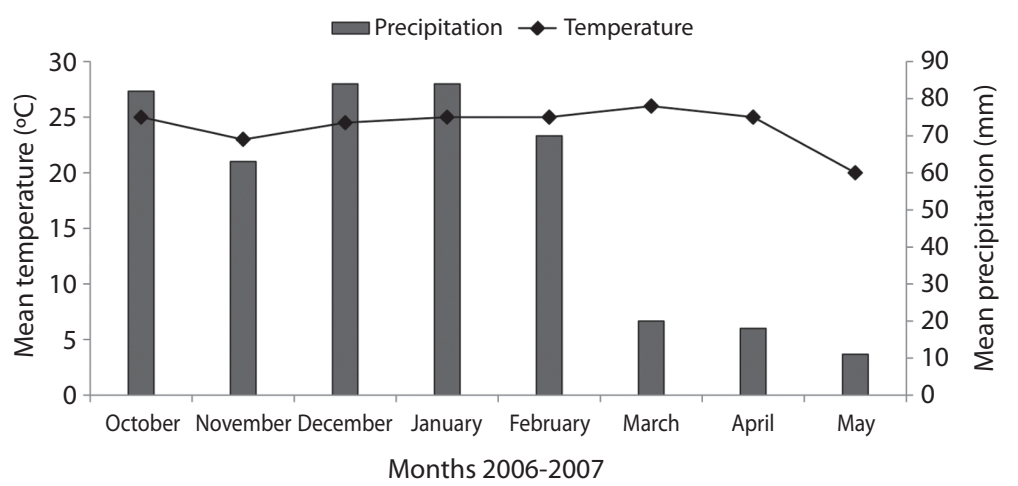

Fig. 1. Climate data (monthly mean temperature and rainfall) for the flowering period of Passiflora alata, in Uberlândia, Southeastern Brazil.

Availability of floral resources in the surroundings of the Passiflora alata culture: The surroundings of $P$. alata plantations at Campo Alegre farm were predominantly pastures and scattered patches of Cerrado stricto sensu. In order to evaluate the availability of floral resources potentially used by E. nigrita, we studied the floristic composition and the flowering phenology in a Cerrado reserve at "Clube de Caça e Pesca Itororó de Uberlândia" (CCPIU), located at $5000 \mathrm{~m}$ away from the studied plantation of $P$. alata. This distance between CCPIU and the studied area is within the flight range of many euglossine bees, which may forage at up to $23 \mathrm{~km}$ from their nest (Janzen 1971). Native flowering plants were sampled along a transect of $1000 \mathrm{~m}$ long and $10 \mathrm{~m}$ wide on each side, thus covering a total of 2ha of Cerrado flora, the dominant vegetation in the region studied. The transect was sampled once a month during the flowering period of P. alata (October 2006-May 2007), recording all flowering species as well as the number of individuals per species. The voucher specimens were deposited in the Herbarium Uberlandense at the Federal University of Uberlândia, Brazil.

Collection of bees for sampling pollen grains: For the collection of pollen grain samples from bees, we captured specimens of $E$. nigrita once a month during the flowering period of $P$. alata from 8:00am-4:00pm (126 sampling hours in total). During that period, the bees were collected in the flowers of P. alata, for $15 \mathrm{~min}$ per hour. This method was adopted in order to not interfere with pollination and fruit production in the study area, because it is a commercial area of $P$. alata. The bees were collected with an insect net and carefully verified in which part of the body (head, thorax, metasoma, corbiculae) the pollen grains were deposited. The pollen grains were sampled following the method suggested by Silva et al. (2010a), which consists of placing the bees into transparent vials containing $1 \mathrm{~mL}$ of water in order to remove the pollen grains attached to the body of the individuals. The individuals were then released and $4 \mathrm{~mL}$ of $70 \%$ alcohol were added in each vial. The material of each collected individual corresponded to one pollen sample, being analysed a total of 47 samples.

Pollen analysis: From each plant species found in the surrounding area, we removed the anthers of at least four individuals in order to set up a reference collection of pollen grains, using acetolysis as proposed by Erdtman (1960). The same method was used for pollen grains samples of the bees. All prepared microscope slides were deposited at the Pollen Slide Collection of 'Laboratório de Morfologia Vegetal, Microscopia e Imagem' (LAMOVI) at the Federal University of Uberlândia (UFU). 
From each bee pollen sample, we mounted three microscope slides that were qualitatively and quantitatively analyzed. For the qualitative analysis we compared the pollen grains removed from the individuals, with the pollen from plants sampled in the surrounding area (Pollen Slide Collection), and also with pollen grains from the region's Pollen List described by Silva et al. (2010b). For the quantitative analysis, we counted the first 400 pollen grains found on each microscope slide as suggested by Montero \& Tormo (1990). From these, we determined the percentages following classification of Barth (1970) and Louveaux et al. (1970, 1978): predominant pollen $(>45 \%$ of total pollen grains on the slide), secondary pollen (from 15-45\%), important minor pollen $(3-15 \%)$ and minor pollen $(<3 \%)$. In this study, those plant species whose pollen grains were found at percentages of more than $15 \%$ in the samples each month, were considered the preferably used plants for obtaining floral resources. In order to evaluate the importance of the native plant species in the surrounding area for the maintenance of E. nigrita populations, we did not consider the pollen grains of the two Passiflora species cultivated in the area in the quantitative analysis.

To determine the use of nectar by $E$. nigrita from flowers of species of native plants, floral traits were evaluated to check if the floral morphology favoured just the collection of nectar, for example, in species with tubular corollas which have nectariferous chamber or narrow floral tube. The flowers were also analyzed as determine the position of the anthers, to understand the process of visit, and if was possible, or not that E. nigrita also collect pollen beyond the nectar. Direct observations were done in the flowers on surrounding cultures whenever possible, to check the behaviour of E. nigrita in the flowers. Additional data were obtained in the literature.

Statistical tests were done using the statistical software BioEstat 5.0 (Ayres et al. 2005). Pearson correlation test was applied to assess the degree of association among climate (monthly mean temperature and rainfall) and availability of floral resources in the areas surrounding the $P$. alata plantation, and the number of bees sampled per month during flowering period of $P$. alata.

\section{RESULTS}

In the study area, flowering of $P$. alata occurred continuously from October 2006 to May 2007, although some peaks of open flowers were observed during the rainy season (October-February). At the beginning of the dry season (March-May) a decrease on flowering was observed. Thirty four females and 13 males of E. nigrita were collected. Of the sampled females, 24 individuals carried pollen on their corbiculae. Fifteen of these pollenloaded females were collected from 8:00am to 11:00am and nine of them from 12:00 noon to $4: 00 \mathrm{pm}$. Female bees were most frequently observed on $P$. alata flowers in October, December, and March whereas males were most abundant in April and May (Fig. 2). No correlation was observed between the number of active bees on flowers and climatic conditions $(\mathrm{r}=0.43, \mathrm{p}=0.28$, for precipitation and $\mathrm{r}=0.13, \mathrm{p}=0.75$, for temperature).

During the collection of bees, we observed that pollen grains were distributed throughout the body of male individuals, but especially on the thorax $(n=13)$; while in the body of females, the pollen grains were observed on the thorax, metasoma and predominantly in the corbiculae $(n=34)$. Among the types of pollen grains accumulated on the thorax of males and females, that of $P$. alata was the predominant. In addition to the pollen of $P$. alata, we found pollen grains from 35 native plant species on females and from 14 species on males. There was an overlap between males and females in the visit of some plant species, being identified in total 40 plant species distributed in 32 genera and 19 botanical families, excluding the pollen grains of the passion fruit species (Table 1).

The use of floral resources by E. nigrita varied in the course of the studied period, with the highest number of pollen types in March, although in this month we observed 


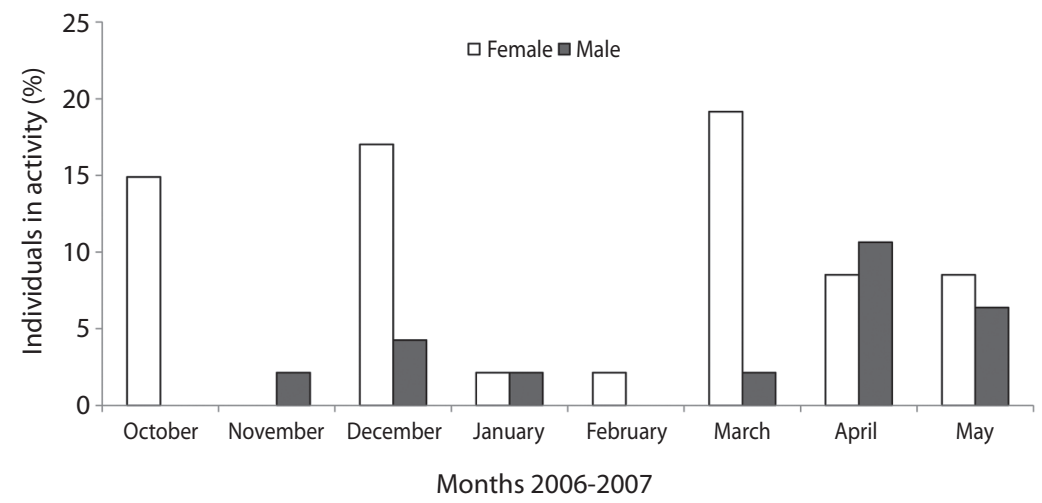

Fig. 2. Percentage of females and males of Eulaema nigrita visiting flowers of $P$. alata from October 2006 to May 2007, in Campo Alegre Farm, Uberlândia, Southeastern Brazil.

one of the lowest numbers of flowering species in the plantation surroundings (Fig. 3). There was no correlation between the number of active individuals and the number of individuals flowering in the area surrounding the sweet passion-fruit plantation $(\mathrm{r}=0.40, \mathrm{p}=0.33$ ) (Fig. 3). However, the number of active bees was correlated with the number of pollen types identified in the bee samples $(\mathrm{r}=0.83, \mathrm{p}=0.01)$ (Fig. 3). The amount of different pollen types carried by bees was strongly associated with the number of plant species providing pollen as pollinator-attractant $(\mathrm{r}=0.98, \mathrm{p}<0.0001)$, but not with the number of species providing nectar $(\mathrm{r}=0.55, \mathrm{p}=0.18)$.

The flowers visited by E. nigrita share several characteristics such as color, shape, type of anther, and size (Table 1). Those plant species represented $25 \%$ of the total of plants visited in each month. The most visited plant species to collect nectar have long corolla, which facilitates access to this flower resource by bees with long tongue, as E. nigrita. The species of plants that provide the pollen as attractive floral

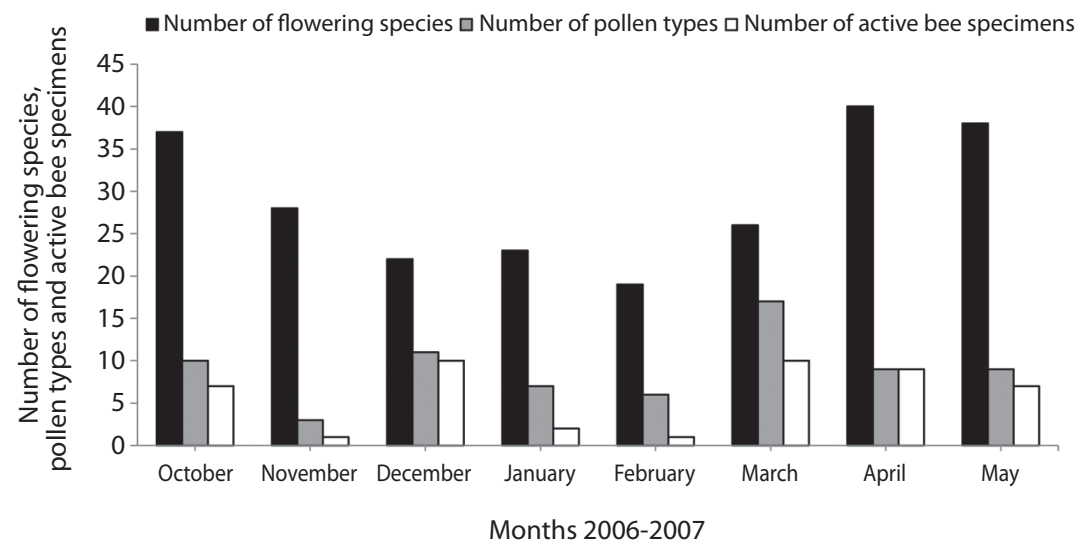

Fig. 3. Number of flowering plants in the surroundings of the plantation of $P$. alata compared with number of pollen types identified in the samples and number of specimens of Eulaema nigrita in activity in the Campo Alegre Farm, Uberlândia, Southeastern Brazil. 


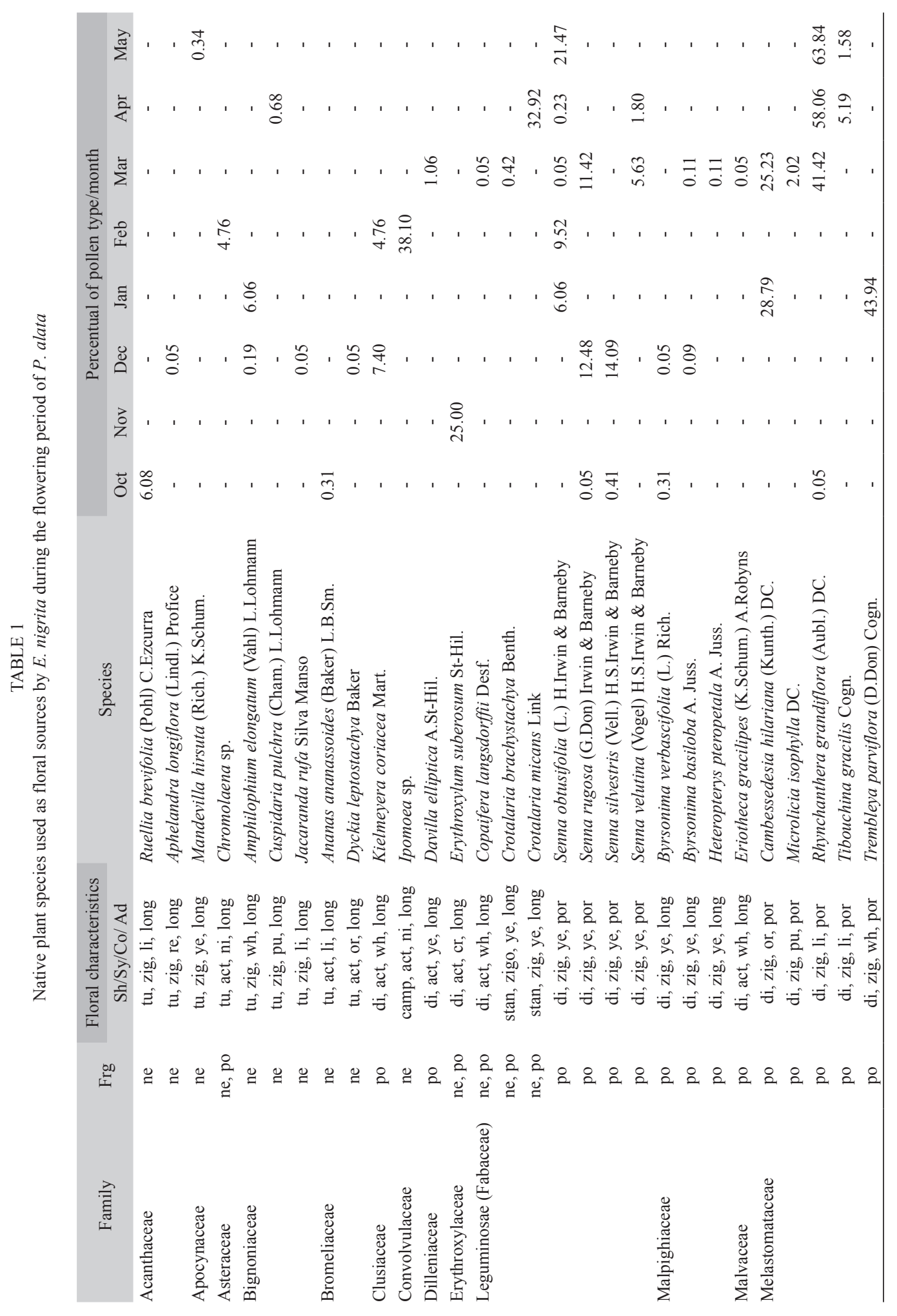




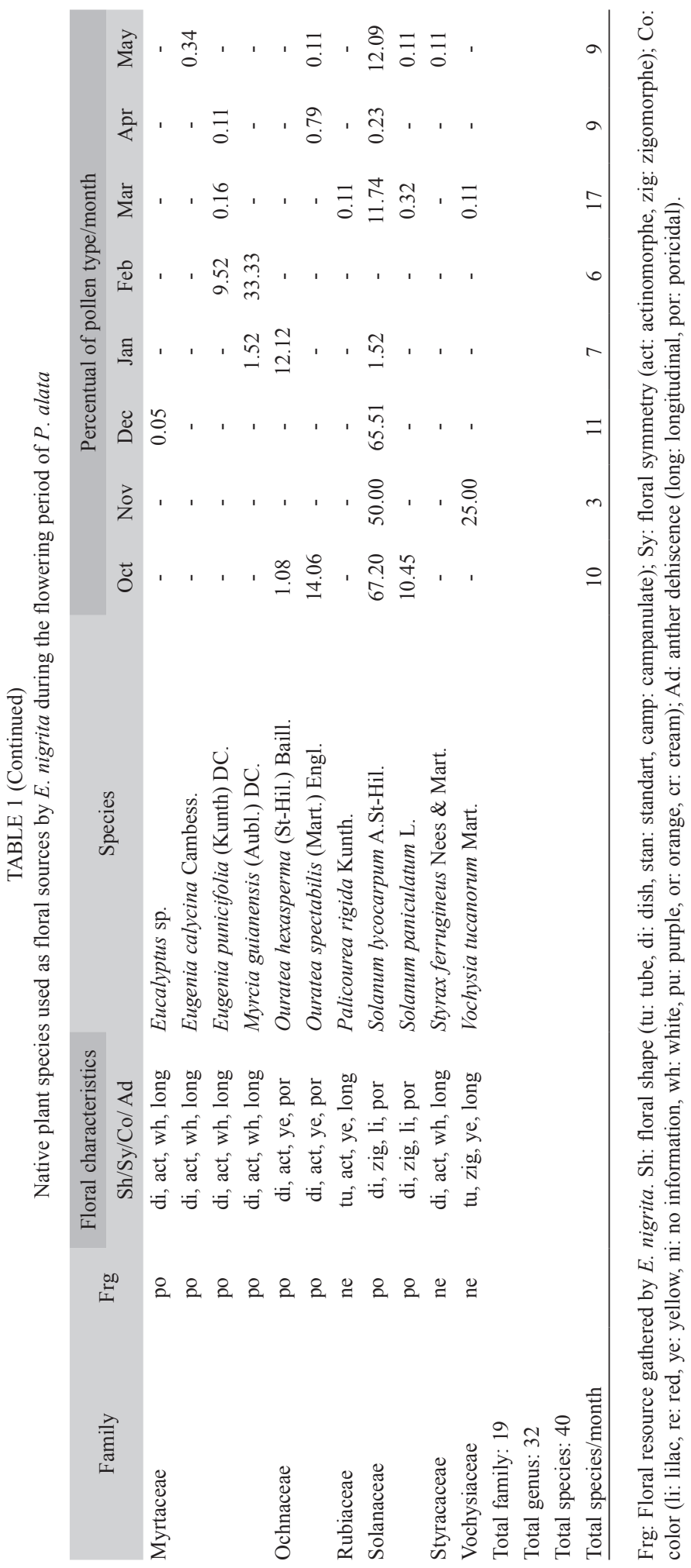


resources in this study have poricidal anthers, that are vibrated by females during visits for pollen grains removal.

In general, E. nigrita visited more native plant species to collect pollen (28 species) than to collect nectar (17 species) (Table 1). The pollen grains most frequently encountered in the bee pollen-samples were from Solanum lycocarpum St. Hil. (Solanaceae) and Rhynchanthera grandiflora (Aubl.) DC. (Melastomataceae). The flowers of these two plant species have poricidal anthers and provide only pollen as floral resource. From the set of species used by E. nigrita, S. lycocarpum and $R$. grandiflora were preferably visited during their flowering periods as indicated by the frequency of pollen grains present in the bee pollen samples (Table 1). Between the flowering season end of $S$. lycocarpum and the beginning of $R$. grandiflora (January and February), other species, such as Trembleya parviflora (D. Don) Cogn. (Melastomataceae), Myrcia guianensis (Aubl.) DC. (Myrtaceae) and Cambessedesia hilariana (Kunth) DC. (Melastomataceae), were the most visited. These three species were visited and/or used as source of floral resources only when $S$. lycocarpum and $R$. grandiflora were not bloom (Fig. 4). Concerning nectar collection, with the exception of $P$. alata that was predominant in all samples, we observed that Crotalaria micans Link (Fabaceae) in April (32.9\%), and Vochysia tucanorum Mart. (Vochysiaceae) in November $(25.0 \%)$, were the plants more visited by E. nigrita (Table 1).

\section{DISCUSSION}

The polyletic foraging pattern of E. nigrita observed in this study, was also reported by Ramírez et al. (2002) and Roubik \& Hanson (2004). This pattern was also exhibited by other species of euglossine bees such as Euglossa atroveneta Dressler, 1978 (Arriaga \& Hernández 1998) and Euglossa annectans Dressler, 1982 (Cortopassi-Laurino et al. 2009).

Eulaema nigrita females collect floral resources on a variety of plants that are not used by males. These males collect only nectar and floral fragrances, as males of other Euglossini species (Dodson et al. 1969, Dressler 1982, Ackerman 1985, Roubik \& Hanson 2004).

The collection of high amounts of pollen and nectar by females of E. nigrita in the study site reflects, mainly, the demand for these resources to the provision of brood cells. Nectar plays an important role not only to feed the brood, but also as an energetic source to the maintenance of adults. The energy expenditures during female foraging for nest-building material and for the provision of cells are very significant due to female's performance of long trips to collect excrement, mud, resin and larval food (Pereira-Martins \& Kerr 1991, Santos \& Garófalo 1994). Euglossine bees collect nectar from tubular flowers and these flowers have nectar with a relatively low concentration of sugar (Roubik et al. 1995), leading females to extend the search for flowers in the field. On the other side, in an opportunistic way, $E$. nigrita may exhibit floral constancy in sources of nectar that are more concentrated and produced in high quantities, as it occurs in flowers of $P$. alata that exhibit on average a sucrose concentration of $39.65 \% \pm 2.63$ and a volume of $408 \mu \mathrm{l} \pm 76.71$ per flower (Rocha 2006). According to Roubik et al. (1995), E. nigrita collects nectar at a concentration ranging from $20-49 \%$. Another factor that may influence the collection of nectar in P. alata is the proximity of the nests to the cultivated area. As reported by Arriaga \& Hernández (1998), the most important plants used by Euglossa atroveneta were near to the nests, and this may be related to energy saving in the flight. However, the pollen analysis indicated that the nectar produced by $P$. alata flowers is not enough to supply the necessary energy to maintain the population of $E$. nigrita. Thus, although $P$. alata has a relatively long flowering period, the samples revealed a wide variety of pollen types from nectarproducing native species, what corroborates the need to preserve the nectariferous plant species in the natural areas near to cultures, especially the species of Acanthaceae, Apocynaceae, Bignoniaceae, Bromeliaceae, Convolvulaceae and Vochysiaceae. All plant species representatives 


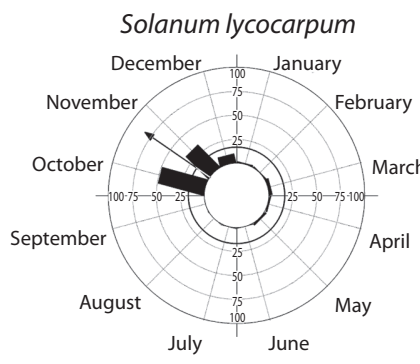

Trembleya parviflora

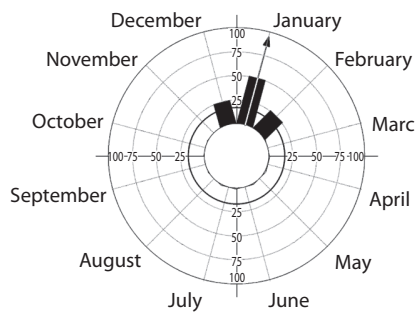

Cambessedesia hilariana

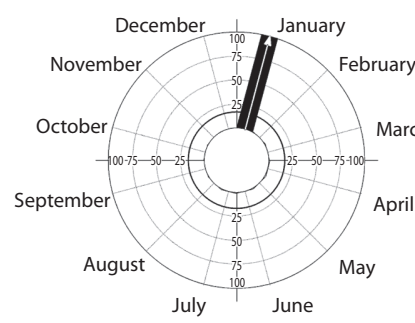

Myrcia rubella

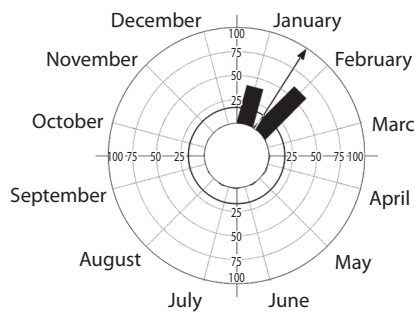

July

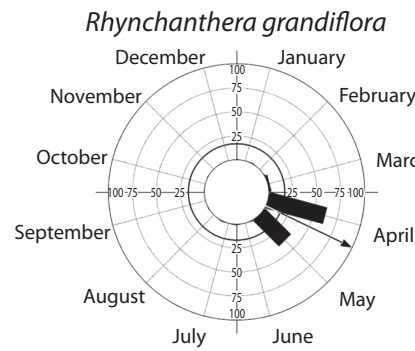

Solanum lycocarpum

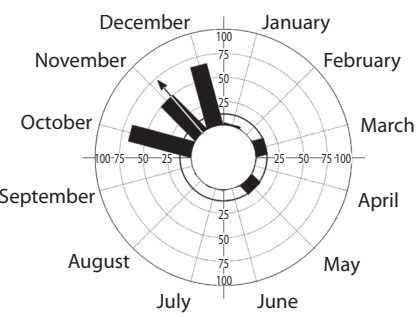

Trembleya parviflora

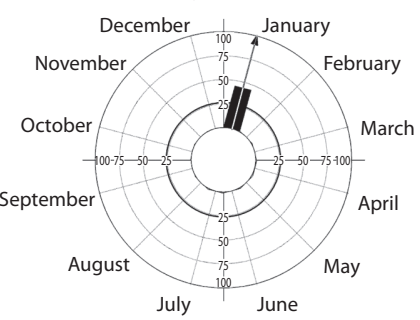

Cambessedesia hilariana

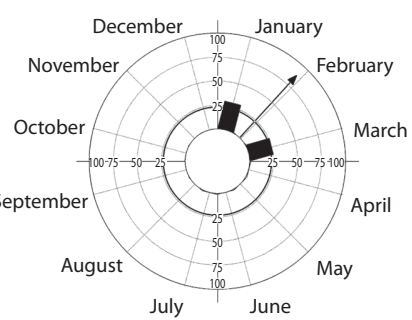

Myrcia rubella

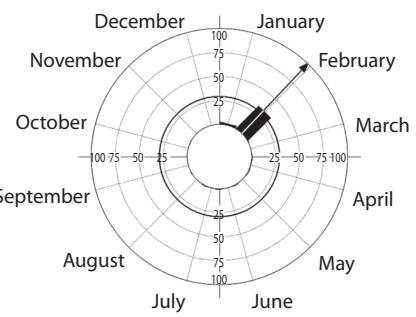

Rhynchanthera grandiflora

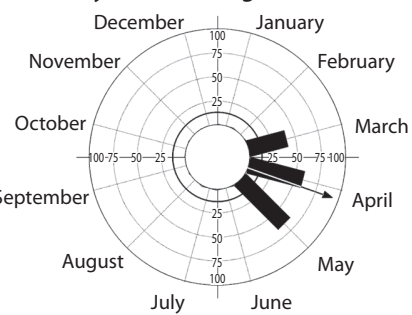

Fig. 4. Percentage of individuals of these most frequently plant species and constantly used by Eulaema nigrita in the surroundings of the plantation of Passiflora alata in Campo Alegre Farm, Uberlândia, Southeastern Brazil. The column left indicate the percentage of flowering individuals of the plant species more visited. The column right indicate the percentage of the pollen grains in this plant species samples. 
of these families identified in this study, analysing the pollen grains removed from the body of E. nigrita, exhibit floral morphology that allows only the collecting of nectar by this bee.

It is important to emphasize again that $P$. alata flowers are used by E. nigrita exclusively to collect nectar and that these bees, as well as the others, need pollen for a balanced diet to survive (Weiner et al. 2010). From June to September E. nigrita depends on other sources than P. alata for the maintenance of nests, and even during its flowering period these bees still need other sources. Quantitative analyses of pollen grains in the samples were important because they revealed the floral constancy in species with poricidal anthers, such as the species of the families Fabaceae (subfamily Caesalpinoidae), Melastomataceae, Ochnaceae and Solanaceae. Pollen grains of these plants were included in the predominant category, corresponding to $12.5 \%$ of all species used by E. nigrita. This shows that these bees sporadically visit a wide variety of plants per month, but prefer a small fraction of them, for example $S$. lycocarpum and $R$. grandiflora. Roulston et al. (2000) observed that pollen grains from species with poricidal anthers exhibit high protein content $(47.8 \%)$, and bees use pollen grains with a percentage between $12-61 \%$. The protein directly influences the larval development of bees (Michener 2000, Minckley \& Roulston 2006). This may justify the floral constancy of E. nigrita on S. lycocarpum and $R$. grandiflora, which blooming during several months throughout the year. The foraging movement between these two species may have occurred due to the variation in the percentage of flowering individuals. This reinforces the preference of E. nigrita females for plants with poricidal anthers. Similar data were observed for other bee species with vibration behavior, in which the predominant pollen grains were the ones from plant species with poricidal anthers, as for example Xylocopa spp. (Silva et al. 2010a) and Centris tarsata Smith, 1874 (Dórea et al. 2009). The pollen analysis enables to obtain quantitative data that are important because they confirm the fact that the plant species that are the most used by bees with vibration behaviour are the ones with more expensive resources, both in terms of protein content of pollen and in terms of energetic content of nectar. The quality of the floral resources must be taken into consideration when making management and conservation plans for pollinators, which has been declining with habitat alteration and reduction of ecological resources used for both feeding and nesting (Cane 2001, Ricketts et al. 2008, Potts et al. 2010, Bommarco et al. 2010).

Despite not being the most often pollinator of P. alata, E. nigrita is a potential pollinator for management in the plantations, since the main pollinator, Epicharis flava (Gaglianone et al. 2010), build their nest in soil, while $E$. nigrita nests in preexisting cavities. Regarding nesting sites, cement blocks with inside cavities used in constructions can be disposed in the field as trap-nests to attract nesting females of E. nigrita, as suggested by Garófalo et al. (2011).

Concerning feeding, the plants preferably visited and used by E. nigrita, which were identified in the present study, must be preserved or reintroduced in the proximities of $P$. alata to favour the maintenance of that species. The management of pollinators in the surroundings of $P$. alata is important, since this plant is a self-incompatible species (Varassin \& Silva 1999), and in the absence of pollinators, growers are forced to pay for hand pollination, which increases production costs (Pereira-Vieira et al. 2010). Keeping pollinators in cultivated areas is still more feasible to ensure sweet passion fruit production.

\section{ACKNOWLEDGMENTS}

The authors thank Celson Martins for sponsor, Márcio Cunha for support in the Campo Alegre Farm; the direction of the Ecological Reserve at 'Clube de Caça e Pesca Itororó de Uberlândia (CCPIU). Thanks to Rosana Romero, Glein Araújo, Flávia Cristina Pinto Garcia, Adriana Arantes do Nascimento and Priscila Oliveira Rosa by identifying the plant 
species. Thanks to the anonymous reviewers for careful analysis and important contribution.

\section{RESUMEN}

La abeja euglosina Eulaema nigrita juega un importante papel para la polinización de las plantas nativas y de importancia económica, como es el caso de la fruta de la pasión o maracuyá Passiflora alata. E. nigrita únicamente recoge el néctar las flores de $P$. alata, sin embargo, tiene que visitar otras plantas para recoger polen, néctar y otros recursos para su supervivencia. Hay dos métodos para identificar las especies de plantas utilizadas por las abejas en su dieta: por observación directa de las abejas en las flores, y a través de la identificación de los granos de polen presentes en las celdas de cría, heces o en el cuerpo de las abejas. Con el fin de identificar las otras plantas que E. nigrita visita, se analizaron muestras de granos de polen extraído del cuerpo de la abeja durante el período de floración de $P$. alata. Entre nuestros resultados, la flora visitada por E. nigrita está compuesta por 40 especies de 32 géneros y 19 familias, algunas de ellas utilizadas como fuente de polen o solamente de néctar. A pesar de ser una especie polifilética, E. nigrita exhibe preferencia por algunas especies de plantas con anteras poricidas. El néctar de $P$. alata tiene la más alta concentración de azúcar y fue la principal fuente de este recurso para las abejas en el área de estudio. Sin embargo, el análisis polínico indicó que otras especies de plantas nectaríferas son necesarias para mantener las poblaciones de E. nigrita. Estudios como éste son importantes pues indican cuales son las fuentes complementarias de néctar y polen que deben ser utilizadas para la conservación de las poblaciones de E. nigrita en los cultivos de las zonas vecinas. En ausencia de polinizadores, los productores se ven obligados a pagar por la polinización manual, lo que aumenta los costos de producción, por lo tanto el mantenimiento de polinizadores en las zonas cultivadas es más factible para asegurar la producción de la fruta de la pasión.

Palabras clave: abeja, análisis polínico, conservación, mantenimiento de los polinizadores.

\section{REFERENCES}

Ackerman, J.D. 1985. Euglossine and their nectar hosts, p. 225-233. In W.G. D'arcy \& M.D. Correa (eds.). The Botany and Natural History of Panama. Miss. Bot. Gard. St. Louis, Missouri, USA.

Almeida, E.C. \& A.L. Pinheiro. 1992. Biologia floral e mecanismo de reprodução em urucuzeiro (Bixa orellana L.) I. tipo "fruto verde piloso", p. 72-81. In Anais da I Reunião Técnico-Científica sobre o Melhoramento Genético do Urucuzeiro. EMBRAPACPATU, Belém, Brazil.
Almeida-Soares, S., L.P. Polatto, J.C.S. Dutra \& H.M. Torezan-Silingardi. 2010. Pollination of Adenocalymma bracteatum (Bignoniaceae): floral biology and visitors. Neotrop. Entomol. 32: 941-948.

Alvarenga, P.E.F., R.F. Freitas \& S.C. Augusto. 2007. Diversidade de Euglossini (Hymenoptera: Apidae) em áreas de cerrado do triângulo mineiro, MG. Biosc. J. 23: 30-37.

Andena, S.R., L.R. Bego \& M.R. Mechi. 2005. A Comunidade de abelhas (Hymenoptera, Apoidea) de uma área de cerrado (Corumbataí, SP) e suas visitas às flores. Rev. Bras. Zoo. 7: 55-91.

Antonini, Y. \& R.P. Martins. 2003. The flowering-visiting bees at the ecological station of the Universidade Federal de Minas Gerais, Belo Horizonte, MG, Brazil. Neotrop. Entomol. 32: 565-575.

Arriaga, E.R. \& E.M. Hernández. 1998. Resources foraged by Euglossa atroveneta (Apidae: Euglossinae) at Unión Juárez, Chiapas, Mexico. A palynological study of larval feeding. Apidologie 29: 347-359.

Ayres, M., M. Ayres Jr., D.L. Ayres \& A.S. Santos. 2005. Programa BioEstat 5.0. Aplicações Estatísticas nas Áreas das Ciências Biológicas e Biomédicas. Sociedade Civil Mamirauá, Belém, Brazil.

Barth, O.M. 1970. Análise microscópica de algumas amostras de mel. 1. Pólen dominante. An. Acad. Bras. Cien. 42: 351-366.

Bommarco, R., J.C. Biesmeijer, B. Meyer, S.G. Potts, J. Poyry, S.P.M. Roberts, I. Steffan-Dewenter \& E. Ockinger. 2010. Dispersal capacity and diet breadth modify the response of wild bees to habitat loss. P. Roy. Soc. B-Biol. Sci. 277: 2075-2082.

Boti, J.J. 2001. Polinização Entomófila da Goiabeira (Psidium guajava L., Myrtaceae): Influência da Distância de Fragmentos Florestais em Santa Teresa, Espírito Santo. Colatina, Master Thesis, Universidade federal de Viçosa, Viçosa, Minas Gerais, Brazil.

Cane, J.H. 2001. Habitat fragmentation and native bees: a premature verdict? Conserv. Ecol. 5: 3 .

Cortopassi-Laurino, M., A. Zillikens \& J. Steiner. 2009. Pollen sources of the orchid bee Euglossa annectans Dressler 1982 (Hymenoptera: Apidae, Euglossini) analyzed from larval provisions. Genet. Mol. Res. 8: 546-556.

Crane, E. \& P. Walker. 1984. Pollination Directory for World Crops. Internat. Bee Res. Association, Bucks, England.

Daily, G.C. 1997. Nature's Services: Societal Dependence on Natural Ecosystems. Island, Washington, USA.

Dodson, C.D., R.L. Dressler, H.C. Hill, R.M. Adams \& N.H. Williams. 1969. Biologically active compounds in orchids fragrances. Science 164: 1234-1249. 
Dórea, M.C., F.A.R. Santos, L.C.L.E. Lima \& L.E.R. Figueroa. 2009. Análise polínica do resíduo pósemergência de ninhos de Centris tarsata Smith (Hymenoptera: Apidae, Centridini). Neotrop. Entomol. 38: 197-202.

Dressler, R.L. 1982. Biology of orchid bees (Euglossini). Annu. Rev. Ecol. Syst. 13: 373-394.

Erdtman, G. 1960. The acetolized method. A revised description. Sven. Bot. Tids. 54: 561-564.

Gaglianone, M.C., H.H.S. Rocha, C.R. Benevides, C.M. Junqueira \& S.C. Augusto. 2010. Importância de Centridini (Apidae) na polonização de plantas de interesse agrícola: o maracujá-doce (Passiflora alata Curtis) como estudo de caso na região Sudeste do Brasil. Oecol. Aust. 14: 152-164.

Garófalo, C.A., E. Camillo \& J.C. Serrano. 2011. Reproductive aspects of Meloetyphlus fuscatus a meloid beetle cleptoparasite of the bee Eulaema nigrita (Hymenoptera, Apidae, Euglossini). Apidologie 42: 337-348.

Gressler, E., M.A. Pizo \& L.P.C. Morellato. 2006. Polinização e dispersão de sementes em Myrtaceae do Brasil. Rev. Bras. Bot. 29: 509-530.

Janzen, D.H. 1971. Euglossine bees as long-distance pollinators of tropical plants. Science 171: 203-205.

Kearns, C.A., D.W. Inouye \& N. Waser. 1998. Endangered mutualisms: the conservation of plant-pollinator interactions. Annu. Rev. Ecol. Syst. 29: 83-112.

Kremen, C.N., M. Williams, M.A. Aizen, B. GemmillHerren, B. Lebuhn, R. Minckley, L. Packer, S.G. Potts, T. Roulston, I. Steffan-Dewenter, D.P. Vázquez, R. Winfree, L. Adams, E.E. Crone, S.S. Greenleaf, T.H. Keitt, A.M. Klein, J.J. Regetz \& T.H. Ricketts. 2007. Pollination and other ecosystem services produced by mobile organisms: a conceptual framework for the effects of land-use change. Ecol. Lett. 10: 299-314.

Louveaux, J., A. Maurizio \& G. Vorwohl. 1970. Methods of melissopalynology. Bee World 51: 25-138.

Louveaux, J., A. Maurizio \& G. Vorwohl. 1978. Methods of melissopalynology. Bee World 59: 139-157.

Maués, M.M. 2002. Reproductive phenology and pollination of the Brazil nut tree (Bertholletia excelsa Humb. \& Bonpl. Lecythidaceae) in Eastern Amazonia, p. 245-254. In P. Kevan \& V.L. Imperatriz-Fonseca (eds.). Pollinating bees. The conservation link between agriculture and nature. Ministry of Environment, Brasília, Brazil.

Michener, C.D. 2000. The Bees of the World. The Johns Hopkins University, Baltimore, USA.

Minckley, R.L. \& T.H. Roulston. 2006. Incidental mutualisms and pollen specialization among bees, p. 69-98. In N.M. Waser \& J. Ollerton (eds.). Plant-Pollinator
Interactions: From Specialization to Generalization. University of Chicago, London, United Kingdom.

Montero, I. \& R. Tormo. 1990. Análisis polínico de mieles de cuatro zonas montañosas de Extremadura. Ann. Asoc. Pal. Leng. Esp. 5: 71-78.

Nabhan, G.P. \& S. Buchmann. 1997. Services provided by pollinators, p. 133-150. In G.C. Daily (ed.). Nature's Services: Societal Dependence on Natural Ecosystems. Island, Washington, USA.

Nascimento, E.A. \& K. Del-Claro. 2007. Floral Visitors of Chamaecrista debilis (Vogel) Irwin \& Barneby (Fabaceae-Caesalpinioideae) at Cerrado of Estação Ecológica de Jataí, São Paulo State, Brazil. Neotrop. Entomol. 36: 619-624.

Nemésio, A. \& L.R.R. Faria Jr. 2004. First assessment of orchid bee fauna (Hymenoptera: Apidae: Apini: Euglossina) of Parque Estadual do Rio Preto, a cerrado area in southeastern Brazil. Lundiana 5: 113-117.

Ollerton, J., R. Winfree \& S. Tarrant. 2011. How many flowering plants are pollinated by animals? Oikos 120: 321-326.

Pereira-Martins, S.R. \& W.E. Kerr. 1991. Biologia de Eulaema nigrita. 1. Contrução de células, oviposição e desenvolvimento. Pap. Avul. Zool. 37: 227-235.

Pereira-Vieira, P.F.S., D.O. Cruz, M.F.M. Gomes, L.A.O. Campos \& J.E. Lima. 2010. Valor econômico da polinização por abelhas mamangavas no cultivo do maracujá-amarelo. Rev. Iber. Econ. Ecol. 15: 43-53.

Potts, S.G., J.C. Biesmeijer, C. Kremen, P. Neumann, O. Schweiger \& W.E. Kunin. 2010. Global pollinator declines: trends, impacts and drivers. Trends. Ecol. Evol. 25: 345-353.

Ramírez, S., R.L. Dressler \& M. Ospina. 2002. Abejas euglosinas (Hymenoptera: Apidae) de la Región Neotropical: listado de especies con notas sobre su biología. Biot. Colomb. 3: 7-118.

Rebêlo, J.M.M. \& C.A. Garófalo. 1997. Comunidade de machos de Euglossini (Hymenoptera: Apidae) em matas semidecíduas do Nordeste do estado de São Paulo. An. Soc. Ent. Bras. 26: 243-255.

Ricketts, T.H., J. Regetz, I. Steffan-Dewenter, S.A. Cunningham, C. Kremen, A. Bogdanski, B. GemmilHerren, S.S. Greenleaf, A.M. Klein, M.M. Mayfield, L.A. Morandin, A. Ochieng \& B.F. Viana. 2008. Landscape effects on crop pollinations services: are there general patterns? Ecol. Lett. 11: 499-515.

Rocha, H.H.S. 2006. Visitantes florais e polinização do Maracujá-doce, Passiflora alata Curtis (Passifloraceae) na Fazenda Campo Alegre, Uberlândia, MG. Monografia, Universidade Federal de Uberlândia, Uberlândia, Brazil.

Roubik, D.W. \& P.E. Hanson. 2004. Orchid bees from tropical America. Biology and field guide. INBio, Santo Domingo, Heredia, Costa Rica. 
Roubik, D.W. 1995. Pollination of cultivated plants in the tropics. FAO Agricultural Services Bulletin No. 118. FAO, Rome, Italy.

Roubik, D.W., D. Yanega, M. Aluja, S.S.L. Buchmann \& D.W. Inouye. 1995. On optimal nectar foraging by some tropical bees (Hymenoptera: Apidae). Apidologie 26: 197-211.

Roulston, T.H., J.H. Cane \& S.L. Buchmann. 2000. What governs protein content of pollen: pollinator preferences, pollen-pistil interactions, or phylogeny? Ecol. Monog. 70: 617-643.

Santos, M.L. \& C.A. Garófalo. 1994. Nesting biology and nest re-use of Eulaema nigrita (Hymenoptera: Apidae, Euglossini). Insect. Soc. 41: 99-110.

Schlindwein, C. 2000. A importância de abelhas especializadas na polinização de plantas nativas e conservação do meio ambiente. Anais do Encontro sobre Abelhas 4: 131-141.

Silva, C.I. 2009. Distribuição espaço-temporal de recursos florais utilizados por Xylocopa spp. e interação com plantas de cerrado sentido restrito no
Triângulo Mineiro. Ph.D. Thesis, Universidade Federal de Uberlândia, Uberlândia, Brazil.

Silva, C.I., M.A.R. Mello \& P.O. Oliveira. 2010a. A palinologia como uma ferramenta importante nos estudos das interações entre Xylocopa spp. e plantas no Cerrado, p. 72-79. In Anais do IX Encontro Sobre Abelhas, FUNPEC, Ribeirão Preto, Brazil.

Silva, C.I., P.L.O. Ballesteros, M.A. Palmero, S.G. Bauermann, A.C.P. Evaldit \& P. E.A.M. Oliveira. 2010b. Catálogo Polínico-Palinologia aplicada em estudos de conservação de abelhas do gênero Xylocopa. UDUFU, Uberlândia, Brazil.

Torezan-Silingardi, H.M. \& K. Del Claro. 1998. Behavior of visitors and reprodutive biology of Campomanesia pubescens (Myrtaceae) in cerrado vegetation. Ciência Cult. 4: 281-284.

Varassin, I.G. \& A.G. Silva. 1999. A melitofilia em Passiflora alata Dryander (Passifloraceae), em vegetação de restinga. Rodriguésia 50: 5-17.

Weiner, C.N., A. Hilpert, M. Werner, K.E. Linsenmair \& N. Blüthgen. 2010. Pollen amino acids and flower specialisation in solitary bees. Apidologie 41: 476-487. 
